\title{
The Effect of Peroral Administration of Amino Acid-Chelated Iron to Pregnant Sows in Preventing Sow and Piglet Anaemia
}

\author{
By A.K. Egeli ${ }^{1}$, T. Framstad ${ }^{1}$ and D. Grønningen ${ }^{2}$
}

${ }^{1}$ Department of Reproduction and Forensic Medicine, Norwegian College of Veterinary Medicine, and ${ }^{2}$ Section of Chemistry, National Veterinary Institute, Oslo, Norway.

\begin{abstract}
Egeli AK, Framstad T, Gronningen D: The effect of peroral administration of amino acid-chelated iron to pregnant sows in preventing sow and piglet anaemia. Acta vet. scand. 1998, 39, 77-87. - Two trials were performed in 2 different pig herds. In Trial 1, 9 pregnant Norwegian landrace sows were given a supplement in the feed of about $300 \mathrm{mg}$ iron daily as amino acid-chelated iron (Bio-plex ${ }^{\circledR}$ ) during the last 3 weeks of gestation. Ten sows were included as controls. In Trial 2, 10 sows were fed a supplement of about $650 \mathrm{mg}$ iron daily as glutamic acid-chelated iron (Super Fe-MAX ${ }^{\circledR}$ ) during the same period of pregnancy as in Trial 1. Twenty-two sows were included as controls. Blood samples were taken from the sows at the start of the experiment and on the day after parturition. The sows in Trial 1 were also bled at weaning 5 weeks after parturition.

The piglets were weighed and blood samples collected $24 \pm 12 \mathrm{~h}$ after birth. Livers were taken from 65 piglets, which were either still-born or which died or were euthanised as one-day olds, and examined for iron content. The erythrocyte count (RBC), haemoglobin concentration (HGB), mean cell volume (MCV), erythrocyte distribution width (RDW), and haemoglobin distribution width (HDW) in blood were measured. Haematocrit (HCT), mean cell haemoglobin (MCH), and mean cell haemoglobin concentration (MCHC) were also estimated. Blood serum was analysed for total proteins, albumin, serum Fe, and total iron-binding capacity (TIBC). A slight increase in HGB and RBC in the piglets from the iron-treated sows compared with the controls was found in Trial 1 , but this was considered to be of no practical importance. None of the other measured parameters were influenced by treating the pregnant sows with amino acid-chelated iron.
\end{abstract}

haematology; clinical biochemistry.

\section{Introduction}

Piglets are born with very small reserves of iron (Venn et al. 1947), and become anaemic soon after birth unless iron is supplemented. Many attempts to prevent the development of anaemia in piglets by treating pregnant sows with iron preparations have failed if subsequent piglet contact with the sow's feed or faeces was prevented (among others: Pond et al. 1961, Miller et al. 1964, Spruill et al. 1971). Some promis- ing results have been achieved with amino acidchelated iron, although the effects have been too small to prevent anaemia during the preweaning period without additional supply of iron from the faeces (Brady et al. 1978, Akabayashi et al. 1989, Ashmead 1993). Amino acid-chelated iron is considered to be absorbed as an amino acid-complex or as small peptides, a higher absorption rate thereby being achieved 
(Ashmead 1993), and is also believed to cross the placental barrier more readily than other iron compounds (Ashmead 1993).

Selective breeding for large litters and high weight gain may at the same time increase sow and piglet iron requirements. Egeli \& Framstad (unpub.) found that already on the day after birth some piglets had an iron deficiency anaemia. Some piglets fail to voluntary consume enough iron supplement, offered in the form of iron solution, during the first week after birth (Egeli \& Framstad unpub.), and iron injections given to piglets in early life may have some adverse side effects (Holmgren 1996, Egeli \& Framstad unpub.). Elevation of the iron stores and HGB level at birth might delay the need for extra iron and improve viability during the first critical days of life.

It has been assumed that sows receive enough iron from commercial feed concentrates. However, around parturition a decrease in HGB occurs, some sows even becoming anaemic (Jain 1986). The pathogenesis of this anaemia is not totally understood (Guise \& Penny 1990).

A procedure of injecting the sows with irondextran before farrowing has been tried in some herds. However, meat staining makes such a procedure undesirable, and, moreover, little information is available on the need for iron supplementation in sows.

The aim of the present study was to evaluate the effect of treating pregnant sows with amino acid-chelated iron during the 3 last weeks of pregnancy. During this period, the foetuses double their weight and iron demands are high (Herbein \& Martin 1975).

\section{Materials and methods}

Trial 1.

This trial took place in the pig farm of the Norwegian College of Veterinary Medicine. Nineteen pregnant sows of the Norwegian landrace breed were divided into 2 groups, a treatment group and a control group. The sows were blocked in accordance with first or later birth number, giving an equal number of primiparous animals in each group. The average litter number ( \pm SD) was $3.0( \pm 2.8)$ for the control sows and $2.3( \pm 1.4)$ for the iron-treated sows. The sows were kept in individual pens during feeding and fed commercial pelleted food containing $75 \mathrm{mg}$ iron per $\mathrm{kg}$ according to standard feeding regimes (1.8-2.5 feed units). From 3 weeks before expected parturition the treatment group, consisting of 9 sows, were given a daily supplement of $15 \mathrm{~g}$ Bio-plex ${ }^{\circledR}$ (Alltech Ireland Ltd, Dublin) dry powder containing about 300 mg amino acid-chelated iron. Control analysis of the powder was carried out by the pharmaceutical company "Hafslund Nycomed", and some variation in iron content was found. The sows were regularly treated for gastrointestinal helminths and vaccinated according to standard regimes against porcine parvovirus, swine erysipelas, and E. coli infections. The piglets were pure Norwegian landrace.

Blood samples were taken from the external jugular vein of the sows before the start of the experiment about 3 weeks before parturition, as well as on the day after parturition and at weaning 5 weeks later. On day 1, 24 $\pm 12 \mathrm{~h}$ after birth the piglets were weighed and blood samples taken. Still-born piglets and piglets that died soon after birth before "day 1" were weighed and autopsied, and the livers were removed and frozen for examination of iron content.

\section{Trial 2.}

This trial took place on a commercial farm, 32 pregnant Norwegian landrace sows being included in the study. As in Trial 1, they were divided into a control group ( 22 sows) and a treatment group (10 sows). The average litter number was $2.9( \pm 1.6)$ for the control sows and $1.8( \pm 1.0)$ for the iron-treated sows. All the 
pregnant sows were kept loose in a room with deep-sawdust, and were fed commercial pelleted food containing $75 \mathrm{mg}$ iron per $\mathrm{kg}$ according to standard feeding regimes ( 2 feed units) from a transponder automatic feeder until 1 to 3 weeks before parturition. From then on, they were kept in farrowing crates on a concrete floor covered with sawdust and fed commercial pelleted food and sour milk in the proportion 1: 3.5 (1.8-2.5 feed units.). From about 3 weeks before parturition, 10 of the sows (treatment group) were given a daily supplement of $25 \mathrm{ml}$ solution of Super Fe-MAX ${ }^{\circledR}$ (Borregaard Ltd, Sarpsborg, Norway) containing about $650 \mathrm{mg}$ glutamic acid-chelated iron.

The sows were free from sarcoptic mange and were regularly treated for gastrointestinal helminths. They were vaccinated according to standard regimes as in Trial 1 . The piglets were crossbred Norwegian landrace and Yorkshire.

Blood samples were collected from 19 of the sows before the experiment started about 3 weeks before parturition, and from all the sows the day after parturition. The piglets were weighed and blood samples taken the day after birth $(24 \pm 12 \mathrm{~h})$. The liver from one still-born piglet or one euthanized piglet from each of 25 litters ( 9 from the treated sows and 16 from the controls) was weighed and frozen for further examination. The euthanized piglets were not bled.

\section{Trials $1 \& 2$.}

Blood from the sows and piglets was collected both in plain tubes and in tubes containing ethylenediaminetetra-acetic acid (EDTA) as an anticoagulant, as previously described (Framstad et al. 1988). Blood samples collected for haematology at week-ends were stored in a refrigerator until Monday morning. The plain tubes were centrifuged for $10 \mathrm{~min}$ at $3000 \mathrm{rpm}$ within $2 \mathrm{~h}$ after collection. The serum samples and livers were kept at minus $25^{\circ} \mathrm{C}$ until analysis.
The leukocyte count (WBC), erythrocyte count (RBC), haemoglobin concentration (HGB), mean cell volume (MCV), erythrocyte distribution width (RDW), and haemoglobin distribution width (HDW) were measured using an automated blood analyser; Technicon $\mathrm{H}^{*} 1^{\circledR}$ (Technicon Instruments Corp., Tarrytown, N.Y.). Haematocrit (HCT), mean cell haemoglobin $(\mathrm{MCH})$, and mean cell haemoglobin concentration $(\mathrm{MCHC})$ were estimated with the Technicon $\mathrm{H}^{*} 1^{\circledR}$ from $\mathrm{RBC}$ and $\mathrm{MCV}$ in $\mathrm{HCT}$, $\mathrm{RBC}$ and $\mathrm{HGB}$ in $\mathrm{MCH}$, and $\mathrm{RBC}, \mathrm{HGB}$ and $\mathrm{MCV}$ in MCHC. The serum was analysed for total proteins, albumin, serum $\mathrm{Fe}$ and totaliron-binding capacity (TIBC) by a Technicon Axon $^{\circledR}$ automated analyser. The livers were homogenised and $\mathrm{Fe}$ determined by flame-atomic absorption spectrophotometry (dinitrogen oxide) with open/closed decomposition (Sivertsen et al. 1995).

In Trial 1, a control sow died in the preweaning period, only the results of the sows with 3 samples being shown in Table 1a (18 sows). In Trial 2 , only the results of the sows with 2 blood samples are shown in Table $1 \mathrm{~b}$ (19 sows). Six sows, 3 in each group in Trial 1 , and 1 sow in the irontreated group in Trial 2, were treated for mastitis, metritis, agalactia (MMA).

In Trial 2, the piglets from 1 control sow and 1 iron-treated sow were excluded because of diarrhoea and serious dehydration on day 1 . Table 2 therefore shows the results pertaining to the piglets from 19 sows in Trial 1 and 30 sows in Trial 2. All the piglets alive the day after birth, except 5 cross-fostered piglets and the 2 excluded litters in Trial 2 were included in the analyses of weight and haematology. Only the piglets which survived to 5 weeks of age were analysed for proteins, serum Fe, and TIBC. The number of piglets (n) for the different parameters listed in Table 2 varies because in some cases, haematological and/or blood chemistry values were lacking due to coagulation of blood 
samples or inadequate amounts of serum to perform the analyses.

Comparison of 2 means was performed by the $t$-test. Comparisons of piglets born alive or born dead between the groups were performed assuming a Chi square distribution, with a level of significance of $5 \%$.

\section{Results}

From Table $1 \mathrm{a}$, it can be seen that in Trial 1, no differences were found in haematological parameters between groups of sows at any sample-time. The control sows showed however, a significant decrease in RBC, HGB $(p<0.05)$, and HCT $(p<0.01)$ from 3 weeks before birth until day 1 , while in the iron-treated sows the decrease in the levels of these parameters was not significant. On day 35 , the haematological parameters were at the same level as on day 1 . Three weeks before parturition, serum Fe was highest in the treatment groups of sows $(p<0.05)$, but on day 1 serum Fe was numerically higher in the control group. There were no significant differences between groups in TIBC, proteins and albumin. In the iron-treated sows, there was a significant decrease in albumin from day 1 to day $35(\mathrm{p}<0.05)$; in the control sows the decrease was not significant.

From Table $1 \mathrm{~b}$, it can be seen that in Trial 2 there was a significant difference between groups of sows in RBC ( $p<0.05)$, HGB and HCT $(p<0.001)$ at the start of the experiment. On day 1 , there was no longer any such difference. RBC, HGB and HCT ( $p<0.05$ in the controls and $p<0.001$ in the iron treated sows) decreased in both groups from 3 weeks before birth until day 1. MCHC increased over the same period $(p<0.05$ in the controls and $p<0.01$ in the iron-treated sows).

There were no differences between groups in serum Fe, TIBC, total proteins and albumin. In both groups, TIBC $(\mathrm{p}<0.001)$ and proteins
( $p<0.01$ in controls and $\mathrm{p}<0.001$ in treated sows) decreased to day 1 .

From Table 1c, it can be seen that the sows in Trial 2 with HGB below $100 \mathrm{~g} / 1$ on day 1, had lower RBC, HGB and HCT $(p<0.001)$, but higher serum $F e(p<0.05)$ than the sows with HGB higher than $100 \mathrm{~g} / \mathrm{l}$. No other parameters differed between the groups.

From Table 2 it can be seen that the mean body weight of the piglets alive on day 1 was the same in the 2 groups in both trials. In Trial 1 , the piglets from the iron-treated sows had higher RBC $(p<0.05)$ and HGB $(p<0.01)$ than the piglets from the control sows. There were no other differences between groups in the parameters listed in Table 2.

The average weight of livers $( \pm S D)$ from the piglets of the iron-treated sows and control sows in Trial 2 was $52.5( \pm 6.9) \mathrm{g}$ and 46.8 $( \pm 14.0) \mathrm{g}$, respectively, the corresponding figures for average total iron content being 6.7 $( \pm 3.8) \mathrm{mg}$ and $7.6( \pm 3.8) \mathrm{mg}$.

In Trial 1, the 9 iron-treated sows delivered 101 live-born piglets and 6 still-born piglets. Seven piglets died during the first day after birth ( 6 because of poor viability and 1 for other reasons). The corresponding figures for the 10 control sows were 110 live-born piglets and 15 stillborn. Twenty-two died during the first day after birth ( 9 due to poor viability and 13 for other reasons). In Trial 2, the 9 iron-treated sows gave birth to 87 live-born piglets and 6 still-born. Three piglets died during the first day after birth. The 21 control sows had 227 live-born piglets and 36 still-born. Eight piglets died during the first day after birth. There were no significant differences between groups of piglets born alive or which were still-born.

\section{Discussion}

These 2 trials revealed that supplying the sows with additional iron during late gestation served 
Table 1a. Haematology and clinical biochemistry in sows receiving $300 \mathrm{mg}$ iron as Bio-plex ${ }^{\circledR}$ daily during the 3 weeks prior to parturition $(\mathrm{Fe}+)$, and the control sows ( $\mathrm{Fe}-$ ) in Trial 1.

\begin{tabular}{|c|c|c|c|c|c|c|}
\hline & \multicolumn{2}{|c|}{$\begin{array}{l}3 \text { weeks before } \\
\text { parturition }\end{array}$} & \multicolumn{2}{|c|}{$\begin{array}{l}\text { The day after } \\
\text { parturition }\end{array}$} & \multicolumn{2}{|c|}{$\begin{array}{c}5 \text { weeks after } \\
\text { parturition }\end{array}$} \\
\hline & $\mathrm{Fe}+$ & $\mathrm{Fe}-$ & $\mathrm{Fe}+$ & $\mathrm{Fe}-$ & $\mathrm{Fe}+$ & $\mathrm{Fe}-$ \\
\hline $\mathrm{n}=$ & 9 & 9 & 9 & 9 & 9 & 9 \\
\hline HGB $(\mathrm{g} / 1)$ & $119(12)$ & $121(9)$ & $112(9)$ & $109(10)$ & $111(11)$ & $106(10)$ \\
\hline $\mathrm{RBC}\left(\times 10^{12} / 1\right)$ & $5.9(0.5)$ & $6.3(0.8)$ & $5.6(0.6)$ & $5.5(0.7)$ & $5.6(0.5)$ & $5.5(0.7)$ \\
\hline HCT (1/1) & $0.37(0.04)$ & $0.37(0.04)$ & $0.35(0.04)$ & $0.33(0.03)$ & $0.35(0.03)$ & $0.33(0.03)$ \\
\hline $\operatorname{MCV}(f)$ & $62.5(3.6)$ & $60.4(3.4)$ & $63.4(4.3)$ & $61.1(3.9)$ & $62.1(4.7)$ & $60.6(3.9)$ \\
\hline $\mathrm{MCH}(\mathrm{pg})$ & $20.1(1.0)$ & $19.4(1.2)$ & $20.1(1.2)$ & $19.8(1.3)$ & $19.8(1.4)$ & $19.3(1.2)$ \\
\hline $\operatorname{MCHC}(g / 1)$ & $323(8)$ & $322(7)$ & $317(11)$ & $323(9)$ & $319(6)$ & $319(10)$ \\
\hline RDW (\%) & 16.9 & 17.0 & 17.3 & 17.8 & 16.5 & 16.7 \\
\hline HDW (g/l) & 20.2 & 20.6 & 20.8 & 22.9 & 20.0 & 22.1 \\
\hline Serum Fe $(\mu \mathrm{mol} / 1)$ & $25(4)$ & $21(4) *$ & $20(8)$ & $23(5)$ & $27(6)$ & $24(5)$ \\
\hline TIBC $(\mu \mathrm{mol} / \mathrm{l})$ & $93(11)$ & $87(11)$ & $89(17)$ & $88(12)$ & $93(11)$ & $86(16)$ \\
\hline$\%$ saturation & 27 & 24 & 23 & 27 & 29 & 28 \\
\hline Serum protein $(\mathrm{g} / \mathrm{l})$ & $71(7)$ & $71(15)$ & $71(7)$ & $68(8)$ & $69(7)$ & $73(8)$ \\
\hline Albumin (g/1) & $37(5)$ & $38(7)$ & $40(5)$ & $39(4)$ & $35(4)$ & $36(5)$ \\
\hline
\end{tabular}

SD in parentheses. ${ }^{*}=\mathrm{p}<0.05$ between groups.

no practical purpose. The parameters measured in the study indicated that amino acid-chelated iron supplementation had very little or no effect on sow and piglet performance.

\section{Piglets}

In Trial 1, the significant difference in HGB and $\mathrm{RBC}$ between groups of piglets on day 1 was nevertheless too slight to have any practical value. Even though it is difficult to compare HGB and RBC between herds, values for these parameters were lower in both groups in Trial 1 than those found in Trial 2, and also lower than found in other studies performed by the authors (Egeli \& Framstad 1997 unpub.). In Trial 2, there were no differences between groups in haematology.

On day 1, HGB could be influenced by difference between piglets in plasma expansion (Jain 1986). The decrease in HGB was by Bollwahn et al. (1972) found to be most rapid during the first $2 \mathrm{~h}$ of life. In the present study there were no differences in HGB between the piglets bled 12-24 and 24-36 $\mathrm{h}$ after birth within the groups, and the sample time was also nearly the same between the groups. Although large individual variation in serum $\mathrm{Fe}$ and TIBC, the standard deviations shown in Table 2 indicate the same exposure to the groups. Although it could have been desirable to follow the piglets in the preweaning period, no parameter in Table 2 inclusive iron content of the livers and birth weight indicates that the groups' performance would differentiate in different directions later in the preweaning period.

Piglet TIBC and serum Fe levels of the piglets found in the present study were quite similar in the 2 herds, but rather low compared to those found by Calvo \& Allue (1986) and Calvo et al. (1989). They do, however, correspond to the findings of Furugouri (1973, 1974a). These differences could be explained by differences in procedures, as different sampling and analytical methods may influence results. In the present 
Table $1 \mathrm{~b}$. Haematology and clinical biochemistry in the sows receiving $650 \mathrm{mg}$ iron as Super Fe-MAX ${ }^{\circledR}$ daily during the 3 weeks prior to parturition ( $\mathrm{Fe}+$ ), and the control sows ( $\mathrm{Fe}-$ ) in Trial 2.

\begin{tabular}{|c|c|c|c|c|}
\hline \multirow[b]{2}{*}{ ' } & \multicolumn{2}{|c|}{3 weeks before parturition } & \multicolumn{2}{|c|}{ The day after parturition } \\
\hline & $\mathrm{Fe}+$ & $\mathrm{Fe}-$ & $\mathrm{Fe}+$ & $\mathrm{Fe}-$ \\
\hline $\mathrm{n}=$ & 10 & 9 & 10 & 9 \\
\hline $\operatorname{HGB}\left(\mathrm{g} / \mathrm{1}^{-1}\right)$ & $123(7)$ & $111(6)^{* *}$ & $104(8)$ & $103(9)$ \\
\hline $\mathrm{RBC}\left(\times 10^{12} / 1^{-1}\right)$ & $6.3(0.3)$ & $5.9(0.5) *$ & $5.0(0.5)$ & $5.2(0.6)$ \\
\hline HCT $\left(1 / 1^{-1}\right)$ & $0.39(0.02)$ & $0.35(0.02) * *$ & $0.32(0.03)$ & $0.31(0.03)$ \\
\hline MCV (fl) & $62.3(4.8)$ & $59.8(3.3)$ & $62.8(5.5)$ & $60.7(3.3)$ \\
\hline $\mathrm{MCH}(\mathrm{pg})$ & $19.7(1.6)$ & $19.1(0.9)$ & $20.7(1.6)$ & $20.1(1.1)$ \\
\hline $\operatorname{MCHC}\left(\mathrm{g} / \mathrm{l}^{-1}\right)$ & $317(11)$ & $319(8)$ & $330(9)$ & $329(8)$ \\
\hline RDW (\%) & 16.8 & 17.1 & 17.1 & 17.0 \\
\hline $\operatorname{HDW}\left(\mathrm{g} / \mathrm{l}^{-1}\right)$ & 16.8 & 17.6 & 19.9 & 17.6 \\
\hline Serum Fe $\left(\mu \mathrm{mol} / 1^{-1}\right)$ & $27(9)$ & $30(8)$ & $25(7)$ & $29(9)$ \\
\hline TIBC $\left(\mu \mathrm{mol} / 1^{-1}\right)$ & $116(12)$ & $121(14)$ & $91(12)$ & $86(8)$ \\
\hline$\%$ saturation & 23 & 25 & 27 & 34 \\
\hline Serum protein $\left(\mathrm{g} / \mathrm{l}^{-1}\right)$ & $77(3)$ & $74(6)$ & $68(6)$ & $65(5)$ \\
\hline Albumin $\left(\mathrm{g} / \mathrm{l}^{-1}\right)$ & $40(2)$ & $38(2)$ & $39(2)$ & $38(3)$ \\
\hline
\end{tabular}

$\mathrm{SD}$ in parentheses. ${ }^{*}=\mathrm{p}<0.05, * *=\mathrm{p}<0.01$ between groups.

trials, blood chemistry analysis was only carried out on the piglets which survived to 5 weeks of age. The haematological values found in these selected piglets were, in both trials and both groups, identical with the haematological values found in all the piglets on day 1 . In Trial 1 , the average birth weight of the selected piglets was slightly higher $(1.80 \mathrm{~kg} \pm 0.38)$ than the overall average of the piglets on day 1 , but there was no difference between groups. In Trial 2, the birth weight was not affected. The production of transferrin and other proteins is low in new-born piglets because of immaturity. The \% saturation is therefore relatively high compared to the sows, even though the serum $\mathrm{Fe}$ is low.

As new-born piglets ingest colostrum, a rapid rise in immunoglobulin levels occurs as a result of the absorption of maternal immunoglobulins (Kaneko 1989). In the present study, serum protein and albumin levels were quite similar in the 2 herds indicating that the amount of colostrum ingested by piglets did not differ much between the herds.

In the present study, total liver iron (i.e. including heme-iron) was measured, results therefore being an overestimation in relation to the true non-heme iron level. Furugouri (1974a) found a non-heme iron content of about $7.3 \mathrm{mg}$ in livers weighing about $41 \mathrm{~g}$, while Venn et al. (1947) found the non-heme iron level to be 5 mg (1.5 kg piglet). Thorén-Tolling (1975) found a total iron content of about $4.6 \mathrm{mg}$ (1.12 $\mathrm{kg}$ piglet). The liver iron levels found in Trial 2 of $6.7 \mathrm{mg}$ and $7.6 \mathrm{mg}$ iron in the 2 groups are thus probably only slight overestimations considering the size of the livers. In any case, this method of estimation should not interfere with comparisons between groups. Furugouri (1973) found great litter and piglet variation in non-heme iron content in liver. Considerable variation in liver iron content was also found in the present study.

Ashmead (1993) assumed that the higher birth 
Table 1c. The haematology and clinical biochemistry of the sows from Trial 2 divided in 2 groups according to $\mathrm{HGB} \geq 100 \mathrm{~g} / \mathrm{l}$ and $\mathrm{HGB}<100 \mathrm{~g} / 1$ the day after parturition.

\begin{tabular}{|c|c|c|}
\hline & \multicolumn{2}{|c|}{ The day after parturition } \\
\hline & $\mathrm{n}=10 \mathrm{HGB}<100 \mathrm{~g} / 1$ & $\mathrm{n}=22 \mathrm{HGB} \geq 100 \mathrm{~g} / \mathrm{l}$ \\
\hline WBC $\left(\times 10^{9} / 1^{-1}\right)$ & $13.2(4.3)$ & $10.5(4.4)$ \\
\hline $\operatorname{HGB}\left(\mathrm{g} / \mathrm{l}^{-1}\right)$ & $95(3)$ & $109(8)^{* * *}$ \\
\hline $\operatorname{RBC}\left(\times 10^{12} / 1^{-1}\right)$ & $4.7(0.2)$ & $5.3(0.5) * * *$ \\
\hline HCT $(1 / 1)$ & $0.29(0.01)$ & $0.33(0.02) * * *$ \\
\hline $\operatorname{MCV}(f)$ & $61.7(2.8)$ & $62.2(4.5)$ \\
\hline $\mathrm{MCH}(\mathrm{pg})$ & $20.4(0.9)$ & $20.6(1.5)$ \\
\hline $\operatorname{MCHC}\left(\mathrm{g} / \mathrm{l}^{-1}\right)$ & $331(7)$ & $332(9)$ \\
\hline RDW (\%) & 17.1 & 17.0 \\
\hline $\operatorname{HDW}\left(\mathrm{g} / \mathrm{l}^{-1}\right)$ & 18.2 & 18.8 \\
\hline Serum $\mathrm{Fe}\left(\mu \mathrm{mol} / \mathrm{l}^{-1}\right)$ & $31(8)$ & $24(7)^{*}$ \\
\hline $\mathrm{TIBC}\left(\mu \mathrm{mol} / \mathrm{l}^{-1}\right)$ & $88(17)$ & $91(13)$ \\
\hline Serum protein $\left(\mathrm{g} / \mathrm{l}^{-1}\right)$ & $67(6)$ & $66(7)$ \\
\hline Albumin $\left(\mathrm{g} / \mathrm{l}^{-1}\right)$ & $37(3)$ & $38(4)$ \\
\hline
\end{tabular}

SD in parantheses. $*=p<0.05, * * *=p<0.001$ between groups.

weight and higher survival rate found in piglets born by treated sows could have been due to the amino acid-chelated iron fed. In Trial 1 in the present study, all the dead piglets were weighed on day 1 . The inclusion of these piglets lowered the average birth weight from 1.73 to $1.66 \mathrm{~kg}$, though the average in the 2 groups was identical. Average birth weight was high in both herds compared to the figures reported in the studies referred to by Ashmead. This indicates that factors other than additional iron supply (assuming that the sow feed is otherwise adequate) are important for birth weight.

Brady et al. (1978) found an increased iron content in milk in sows given $850-1700 \mathrm{mg}$ iron as proteinate daily. The piglets in the experimental group had numerically higher body iron and plasma Fe levels, and significantly higher HGB levels at birth. The iron content in the sows'milk was far to low to prevent anaemia, and the authors suggested that the main source of iron for the piglets was the sows' faeces during the preweaning period. When a lesser amount of iron was given, no effect was achieved. Akabayashi et al. (1989) found an increased level of serum ferritin, a small increase in HGB, and enhanced viability in new-born piglets from sows given 600-1200 mg iron daily the 8 last weeks of gestation. In the present study, 2 different products were evaluated, and $300-650 \mathrm{mg}$ iron were given daily during the last 3 weeks of gestation. The lack of effect in the piglets could be explained by insufficient intestinal absorption of iron, or by failure of iron to cross the placental barrier in adequate amounts. It is, however, possible that the administration of larger amounts of iron would exert some effect. Calvo et al. (1989) found a relationship between serum ferritin levels in sows and their offspring, but considered that the doses of iron administered to the sows which would be sufficient to prevent the piglets from becoming anaemic would have to be so large that they would probably be toxic. The economic costs and possible adverse effect of feeding sows extremely large amounts of iron to achieve only a small increase in the piglets' iron stores exclude such a procedure. 
Table 2. Body weight, haematology and clinical biochemistry on the day after birth in the piglets in Trial 1 and Trial 2, and the iron content in the livers of piglets.

\begin{tabular}{|c|c|c|c|c|c|c|c|c|}
\hline & \multicolumn{4}{|c|}{ TRIAL 1} & \multicolumn{4}{|c|}{ TRIAL 2} \\
\hline & $\mathrm{Fe}+$ & $\mathrm{n}$ & $\mathrm{Fe}-$ & $\mathrm{n}$ & $\mathrm{Fe}+$ & $\mathrm{n}$ & Fe- & $\mathrm{n}$ \\
\hline Weight (kg) & $1.73(0.43)$ & 94 & $1.73(0.40)$ & 88 & $1.83(0.38)$ & 84 & $1.83(0.42)$ & 214 \\
\hline $\operatorname{HGB}\left(g / 1^{-1}\right)$ & $83(11)$ & 94 & $78(12) * *$ & 88 & $88(14)$ & 84 & $89(15)$ & 210 \\
\hline $\operatorname{RBC}\left(\times 10^{12} / 1^{-1}\right)$ & $3.9(0.6)$ & 94 & $3.7(0.7)^{*}$ & 88 & $4.2(0.8)$ & 84 & $4.3(0.7)$ & 210 \\
\hline $\operatorname{MCV}(\mathrm{fl})$ & $69.8(7.1)$ & 94 & $69.0(6.0)$ & 88 & $66.7(4.0)$ & 84 & $66.7(4.0)$ & 210 \\
\hline RDW (\%) & 18.3 & 94 & 18.5 & 88 & 17.1 & 84 & 17.3 & 210 \\
\hline HDW $\left(g / 1^{-1}\right)$ & 33.3 & 94 & 33.8 & 88 & 31.4 & 84 & 30.9 & 210 \\
\hline Serum Fe $\left(\mu \mathrm{mol} / 1^{-1}\right)$ & $10(5)$ & 70 & $9(5)$ & 62 & $11(4)$ & 83 & $11(5)$ & 205 \\
\hline TIBC $\left(\mu \mathrm{mol} / 1^{-1}\right)$ & $32(11)$ & 67 & $35(12)$ & 62 & $36(9)$ & 84 & $38(14)$ & 199 \\
\hline Saturation \% & 30 & & 26 & & 32 & & 29 & \\
\hline Serum proteins $\left(\mathrm{g} / \mathrm{l}^{-1}\right)$ & $54(11)$ & 70 & $56(13)$ & 62 & $51(9)$ & 80 & $51(11)$ & 205 \\
\hline albumin $\left(\mathrm{g} / \mathrm{l}^{-1}\right)$ & $11(2)$ & 70 & $11(2)$ & 62 & $11(2)$ & 84 & $10(3)$ & 205 \\
\hline liver $\mathrm{Fe}\left(\mathrm{mg} \mathrm{Fe} / \mathrm{kg}^{-1}\right)$ & $278(154)$ & 13 & $219(109)$ & 27 & $128(74)$ & 9 & $163(56)$ & 16 \\
\hline
\end{tabular}

SD in parentheses. $*=p<0.05, * *=p<0.01$ between groups.

$\mathrm{Fe}+=$ Piglets from sows receiving iron supplementation during the last 3 weeks of gestation.

$\mathrm{Fe}-=$ Piglets from the control sows.

In the present trial, the still-born piglets are difficult to evaluate because of rather few sows and the many other factors which influence the number piglets born alive. It seems unlikely that the iron treatment given would have resulted in more live-born piglets and fewer stillborn or low-viability piglets due to better oxygenation of the foetuses, when no other parameters indicated any positive effect of iron treatment. There were indeed no significant differences between groups with regard to numbers of live-born, still-born, and low viability piglets in Trial 1. In Trial 2, the higher number of piglets born alive by the treated sows was nearly significant. However, in this trial, the data regarding still-born piglets were based on the farmer's observations, which makes the results uncertain. The control sows in this herd were older than those in the treatment group and gave birth to a larger overall number of piglets. Both these factors have been found to be positively correlated to the number of still- born piglets (Bille et al. 1974, Spicer et al. 1986).

\section{Sows}

The results for some of the parameters measured in the sows were complicated by differences in values between groups before the start of the experiment. On day 1 , these differences were no longer apparent, and on this day the haematology and blood chemistry of the sows were almost identical between groups in both trials. Serum $\mathrm{Fe}$ was quite constant in the present trials and within the reference range given by Kaneko (1989). TIBC seemed to vary more between herds and time. TIBC was very high in Trial 2, 3 weeks before parturition, and higher than the reference range.

HGB and RBC are expected to decrease as parturition approaches (Jain 1986). Some sows even become anaemic, although the pathogenesis is not fully understood. The higher blood volume found in late gestation and during lac- 
tation could explain the lower HGB (Jezkova et al. 1977, Steinhardt et al. 1981). Moore et al. (1965) suggested that an iron deficiency anaemia was present in some sows. There was a decrease in RBC, HGB and HCT from 3 weeks before parturition to day 1 in both herds and groups. Average HGB and RBC levels in the sows were at this time at the lower end of the reference range given for sows (Jain 1986, Evans 1994, Friendship \& Henry 1984). Assuming the limit for anaemia in sows to be 100 $\mathrm{g}$ haemoglobin $/ 1,2$ control sows and 1 irontreated sow in Trial 1 were anaemic (i.e. HGB below this level) on day 1 . Five weeks after parturition the number of anaemic sows had increased to 5. In Trial 2, as many as 7 control sows and 3 iron-treated sows, out of a total of 32 sows, had HGB below $100 \mathrm{~g} / 1$ on day 1 .

Comparison of the 10 sows with HGB below $100 \mathrm{~g} / 1$ with the others in Trial 2, revealed differences in RBC and HCT in addition to HGB, though not in other parameters except for serum $\mathrm{Fe}$, which was even significantly higher in the sows with lowest HGB. MCV, RDW, and HDW have been found to be very sensitive indicators of iron deficiency anaemia in piglets (Holter et al. 1991, Egeli \& Framstad 1997 unpub.). In light of the clinical biochemistry and haematological findings, an iron deficiency does not seem to be the reason for the low HGB in Trial 2. Petersen et al. (1979) found decreasing HGB levels with age of the sows. Most of the sows in the present trials were relatively young, and there was no relationship between age and the levels found. Jain (1986) largely attributed the decrease in HGB to changes in blood volume and the consequent dilution effect during birth and lactation. This could also explain the decrease in TIBC and proteins found in Trial 2. Guise \& Penny (1990) suggested that a hormonally induced suppressive effect on bone marrow might result in a normocytic, normochromic anaemia at the end of pregnancy in sows. Haematological findings in the present study cannot exclude a dilution effect and depression of the bone marrow's production of RBC.

Frobish \& Lillie (1976) did not manage to raise the HGB level by injecting sows with $500 \mathrm{mg}$ iron as a single dose iron-dextran 2 weeks before parturition. Xian-Ming et al. (1993) found only a numerical effect on HGB level in sows given $1000 \mathrm{mg}$ amino acid-chelated iron daily from 28 days before term. Akabayashi et al. (1989) fed sows 600-1200 mg amino acid-chelated iron from 8 weeks prior to birth and found a tendency towards higher serum ferritin level in these sows at parturition compared both with sows given the same amount of iron salt and untreated controls. In the present trial, 300-650 mg iron were given to sows daily over the last 3 weeks of pregnancy with no effect on their blood picture. A utilisation rate of up to $36 \%$ was found in Norwegian landrace piglets when given iron in the form of the glutamic acid-chelated iron compound (Egeli \& Framstad 1996). The mentioned studies would seem to indicate that it is very difficult to raise the low HGB levels found in sows before farrowing by iron supplementation, and that an iron deficiency is probably not involved.

\section{References}

Akabayashi TW, Yamamoto M, Hirai Y, Yoshino Y: Absorption and availability of iron peptide in pregnant sows. Bull. Nippon vet. zootech. Coll. 1989, 38, 93-105.

Ashmead HD: Comparative intestinal absorption and subsequent metabolism of metal amino acid chelates and inorganic metal salts. In: Ashmead HD (author) The roles of amino acid chelates in animal nutrition. Noyes Publications. Park Ridge, New Jersey. 1993, 47-75.

Ashmead HD: The role of iron amino acid chelate in pig performance. In: Ashmead HD The roles of amino acid chelates in animal nutrition. Noyes Publications. Park Ridge, New Jersey. 1993, 207230.

Bille N, Nielsen NC, Larsen JL, Svendsen J: Pre- 
weaning mortality in pigs. 2 . The perinatal period. Nord. Vet.-Med. 1974, 26, 294-313.

Bollwahn W, Vaske T, Rojas M, Wenz I: The haematopoiesis of newborn piglets and the effect of iron dextran $\left({ }^{\circledR}\right.$ Myofer). Blue Book Vet. Prof. 22, 152162.

Brady PS, Pao KK, Ullrey DE, Miller ER: Evaluation of an amino acid-iron chelate hematinic for the baby pig. J. Anim. Sci. 1978, 47, 1135-1140.

Calvo JJ, Allue JR: Plasma ferritin and other parameters related to iron metabolism in piglets. Comp. Biochem. Physiol. 1986, 85A, 471-476.

Calvo JJ, Allue JR, Escudero A, García LJ: Plasma ferritin of sows during pregnancy and lactation. Cornell Vet 1989, 79, 273-282.

Egeli AK, Framstad T: Chelated iron supplementation in piglets. Proceedings of the 14th International Pig Veterinary Society Congress, Bologna, Italy 1996, 439.

Evans RJ: Porcine haematology: Reference ranges and the clinical value of haematological examination in the pig. Pig J. 1994, 32, 52-57.

Framstad T, Sjaastad ØV, Aass R: Blodprøvetaking på gris. (Blood sampling in pigs) Norsk Vet.-T. 1988, 100, 265-273.

Friendship RM, Lumsden JH, McMillan I, Wilson $M R$ : Hematology and biochemistry reference values for Ontario swine. Can. J. comp. Med. 1984, 48, 390-393.

Frobish LT, Lillie RJ: Proceedings of the 4th International Pig Veterinary Society Congress, Ames, Iowa. 1976, V6. (Physiology)

Furugouri K: Developmental changes in the nonheme iron composition of the liver and spleen in piglets. J. Anim. Sci. 1973, 36, 265-270.

Furugouri, $K$ : Non-heme iron mobilization from the liver in piglets. Jap. J. vet. Sci. 1974a, 36, 255-261.

Guise HJ, Penny RHC: Influence of supplementary iron in late pregnancy on the performance of sows and litters. Vet. Rec. 1990, 127, 403-405.

Herbein JH, Martin RJ: Response to insulin in the fetal and newborn pig. J. Anim. Sci. 1975, 41, 316.

Holmgren N: Polyarthritis in piglets caused by iron dextran. Proceedings of the 14th International Pig Veterinary Society Congress, Bologna, Italy 1996, 306.

Holter PH, Framstad T, Aulie A, Refsum HE, Sjaastad $\varnothing V$ : Effect of iron treatment on erythrocyte parameters in postnatal anemia of the pig. Pediatr. Hematol. Oncol. 1991, 8, 1-11.

Jain NC: The pig: Normal hematology with comments on response to disease. In: Jain NC
Schalm: Veterinary Hematology. 4th ed. Lea \& Febiger. Philadelphia. 1986, 240-255.

Jezkova D, Smrckova M, Padalikova D: Changes in the plasma volume, total blood volume and haematocrit values of pregnant sows. Acta vet. Brno. 1977, 46, 203-212.

Kaneko JJ: Appendix VII: Normal blood analyte values in large animals. In: Kaneko JJ (ed.) Clinical biochemistry of domestic animals. 4th ed. Academic Press. San Diego, California. 1989, 888.

Miller ER, Ullrey DE, Zutaut CL, Vincént BH, Ellis $D J$, Luecke RW, Hoefer JA: Supplementation of sow lactation diet with ferrous fumarate. J. Anim. Sci. 1964, 23, 884-885.

Moore RW, Redmond HE, Livingston CW: Iron deficiency anemia as a cause of stillbirths in swine. J. Amer. vet. med. Ass. 1965, 147, 746-748.

Petersen ES, Laue H, Nielsen HE: Sow haemoglobin values. Influence of sow age and reproductive performance effect. Acta Agric. Scand. 1979, 29, 45-48.

Pond WG, Lowery RS, Maner JH, Loosli JK: Parental iron administration to sows during gestation or lactation. J. Anim. Sci. 1961, 20, 747-750.

Sivertsen T, Daae HL, Godal A, Sand G: Ruminant uptake of nickel and other elements from industrial air pollution in the Norwegian-Russian border area. Environ. Pollut. 1995, 90, 75-81.

Spicer EM, Driesen SJ, Fahy VA, Horton BJ, Sims LD, Jones RT, Cutler RS, Prime RW: Causes of preweaning mortality on a large intensive piggery. Aust. vet. J. 1986, 63, 71-75.

Spruill DG, Hays VW, Cromwell GL: Effects of dietary protein and iron on reproduction and iron-related blood constituents in swine. J. Anim. Sci. 1971, 33, 376-384.

Steinhardt M, Furcht G, Füssel AE, Hörügel $K$, Grumbach $R$ : Beziehungen zwishen einigen Konzentrations- und Mengenmaßen des Blutes von Sauen. (Relationship between certain values for blood concentration and blood volume in sows.) Arch. exp. Vet.-Med. 1981, 35, 707-714.

Thorèn-Tolling $K$ : Studies on the absorption of iron after oral administration in piglets. Acta Vet. Scand. (Suppl) 1975, 54, 1-121.

Venn JAJ, McCance RA, Widdowson EM: Iron metabolism in piglet anaemia. J. comp. Path. 1947, 57, 314-325.

Xian-Ming C, Lian FM, Ping ZY: The effect of iron amino acid chelate on the prevention of anemia. In: Ashmead HD The roles of amino acid chelates in animal nutrition. Noyes Publications. Park Ridge, New Jersey. 1993, 231-242. 


\section{Sammendrag}

Effekten av peroral administration av amino syrechelatert jern til drektige purker $i$ å forebygge anemi hos purker og grisunger.

To forsøk $\mathrm{i}$ forskjellige besetninger ble utført. I Forsøk 1 ble 9 Norsk Landsvin purker gitt ca. $300 \mathrm{mg}$ jern daglig som amino syre-chelatert-jern (Bioplex $\left.^{\circledR}\right)$, de tre siste ukene av drektigheten. Ti purker var kontroller. I forsøk 2 ble 10 purker gitt ca. $650 \mathrm{mg}$ jern daglig som glutamin syre-chelatert-jern (Super Fe-MAX ${ }^{\circledR}$ ) i den samme tidsperioden som forsøk 1. Tjue-to purker var kontroller. Blodprøver av purkene ble tatt ved forsøkets start og dagen etter grising. Det ble tatt prøve av purkene i forsøk 1 også ved avvenning, 5 uker etter grising.

Grisungene ble veid og det ble tatt blodprøve $24 \pm 12$ timer etter fødselen. Levrene ble analysert for jerninnhold hos 65 døde grisunger. Haematologi ble analysert ved en automatisk hematologi maskin; Technicon $\mathrm{H}^{*} 1$. Klinisk biokjemi ble analysert ved en Axon ${ }^{\circledR}$ maskin. En liten økning i hemoglobin konsentrasjon, erytrocytter og hematokrit hos grisungene til de jernbehandlede purkene, sammenlignet med kontroll purkene ble funnet i forsøk 1 , men dette ble vurdert uten praktisk betydning. Det ble ikke funnet noen effekt av behandlingen i de andre målte parametre.

(Received August 4, 1997; accepted November 1, 1997).

Reprints may be obtained from: A.K. Egeli, Department of Reproduction and Formic Medicine, Norwegian College of Veterinary Medicine. P.O. Box 8146 Dep. N-0033, Oslo, Norway. E-mail: A.K.Egeli@veths.No, tel: +47 229648 71, fax: +4722597083. 